\title{
食品のエネルギー值の算出方法についての検討： 組成に基づく方法と従来法との比較
}

\author{
松 本 万 里, 渡 邊 智 子 ${ }^{*, 2,3}$, 松 本 信 二1, 安 井 明 美 ${ }^{2,4}$
}

（2020 年 9 月 21 日受付；2020 年 10 月 16 日受理)

\begin{abstract}
要旨：目的：組成に基づく成分值を基礎とした食品のエネルギー值（アミノ酸組成, 脂肪酸組成, 炭水化物 組成などを用いた FAO が提唱する方法, 組成エネルギー值）と従来法によるエネルギー值の相違を明らか にすることを目的とした。方法：日本食品標準成分表 2015 年版（七訂）の収載食品を対象に可食部 $100 \mathrm{~g}$ 当たりの組成エネルギー值を算出し，既収載のエネルギー值（既収載值）と比較した。さらに，平成 26 年 国民健康・栄養調査の食品別摂取量から, 組成エネルギー值および既収載値を用いてエネルギー摂取量を算 出し，両者を比較した。結果：可食部 $100 \mathrm{~g}$ 当たりの組成エネルギー值（a）と既収載值（b）との一致率

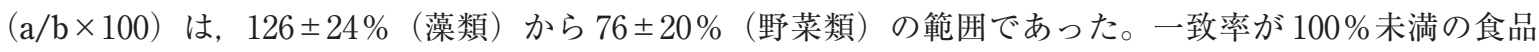
群は 14 群であり, 全食品の一致率は $91 \pm 17 \%$ であった。一致率 80-100\%の範囲に対象食品の $68 \%$ $\%$ 含まれ, 一致率 60-80\%に対象食品の 13\%が，一致率 100-120\%に対象食品の 12\%が含まれていた。国民健康・栄養 調査の食品別摂取量を基に, 組成エネルギー值を用いて算出した総エネルギー摂取量と, 既収載值を用いて 算出した総エネルギー摂取量との一致率は, $92 \%$ あった。
\end{abstract}
キーワード：エネルギー，組成によるエネルギー，アミノ酸組成によるたんぱく質，トリアシルグリセロー ル当量, 利用可能炭水化物

食品のエネルギー値は，食品を評価する重要な指標の 1つである。エネルギー值は, エネルギー産生栄養素量 にエネルギー換算係数を乗じて算出する。エネルギー産 生栄養素の分析方法による值の相違や選択するエネル ギー換算係数の相違がエネルギー值に影響する。また, 国際的には，食品やその成分に適用される換算係数は統 一されていない。

日本食品標準成分表 2015 年版 (七訂) (成分表 2015) ${ }^{1)}$ では, 食品のエネルギー值について, 当該食品の一般成 分として収載されるたんぱく質, 脂質および炭水化物, 並びに，その他のエネルギー産生成分として酢酸，アル コールの質量を基数として，それぞれ個別食品について のヒト消化性の検証結果から得られた『食品ごとのエネ ルギー換算係数』を乗じて算出している。

一般成分に基づく食品のエネルギー計算については, 一般成分の燃焼エネルギーおよびヒト消化性試験の評価 結果に基づき，1910年に，たんぱく質，脂質および炭 水化物に各々 4:9:4 を乗ずる Atwater 係数 ${ }^{2)}$ が基本とさ
れた。しかし，この係数は当時のアメリカの食事を前提 として研究されたものであることから，1947 年の FAO 報告においては，個別食品・一般成分単位でヒト消化性 が評価されたものについて，個別に修正係数を適用する 方法 (修正 Atwater 法) ${ }^{3)}$ が奨励された。そのため, 食品 別にヒト試験等を実施し，たんぱく質，脂質および炭水 化物について, Atwater 係数を補正して利用する取り組 みが行われてきた。

修正 Atwater 法については, ヒト消化性試験において 個人差の存在を除くことができず，また多様な食品にき め細かく対応していくことが難しいこと, 古典的な一般 成分分析では把握されていないアミノ酸, 脂肪酸, 利用 可能炭水化物等の一般成分中の組成成分構成が食品ごと に異なること等が，その算定に当たっての不確かさ要因 として指摘されている ${ }^{4)}$ 。また, ヒト試験で有意な結果 が得られなかったきのこ類, 藻類等については, 四訂日 本食品標準成分表 (四訂成分表) ${ }^{5)}$ ではエネルギーを算 出しないこととしたが, その後, 栄養計算上何らかの值

\footnotetext{
*連絡者・別刷請求先（E-mail: tomoko.watanabe@soc.shukutoku.ac.jp）

1 文部科学省科学技術・学術政策局政策課資源室（100-8959 東京都千代田区霞が関 3-2-2)

2 文部科学省科学技術・学術審議会資源調查分科会食品成分委員会 (100-8959 東京都千代田区霞が関 3-2-2)

3 淑徳大学看護栄養学部栄養学科（260-8703 千葉市中央区仁戸名町 673)

4 国立研究開発法人農業・食品産業技術総合研究機構食品研究部門 (305-8642 茨城県つくば市観音台 2-1-12)
} 
を必要とする現場のニーズに対応する形で，五訂日本食 品標準成分表 (五訂成分表 $)^{6}$ 以降は, これらの食品の エネルギー計算の暫定的な措置として, Atwater 倸数で 算出された值の $1 / 2$ をエネルギー值とした。この暫定措 置は，成分表 2015 でも踏襲されている。

これらの修正 Atwater 法の欠点を補うエネルギー算出 法として，成分分析技術が向上したことを背景としたア ミノ酸, 脂肪酸, 単糖類, 多糖類等の一般成分を構成す る『組成成分ごとの換算係数』を乗ずる方法が，国際的 に推奨されている4)。国内に扔いても，食品表示法に基 づくエネルギー表示の手順に扔いては, 難消化性の化合 物に対して中間的なエネルギー換算係数が適用されてい る7。一方, 我が国の日本食品標準成分表においては,

従来，一般成分を構成する組成成分量の充実強化につい て調查検討を進めてきた。2015 年の日本食品標準成分 表の全面改訂に打いては, 「日本食品標準成分表 2015 年 版 (七訂) アミノ酸成分表編 $\rfloor^{8}$, 「旦本食品標準成分表 2015 年版（七訂）脂肪酸成分表編 」9), 「日本食品標準成 分表 2015 年版 (七訂) 炭水化物成分表編 $\rfloor^{10)}$ を成分表 2015 と同時に公表し，たんぱく質，脂質および炭水化 物の主要 3 成分について, エネルギー值の算出にそれぞ れの構成成分の成分值を参照することが可能な状況と なっている。

そこで，資源調査分科会食品成分委員会では，諸外国 でのエネルギー算定法も参照しつつ, 組成成分を基礎と してエネルギー值を算出する方法を検討し，2019年末 の委員会に打いて, 次期改訂以降のエネルギー計算に適 用する方針を確認した。本稿では，この検討に際して実 施した, 成分表 2015 の収載食品を対象とする当該方法 と従来法によるエネルギー值の相違の検証プロセスと, その結果から得られた知見を報告する。

\section{方}

\section{法}

\section{1. 対象食品}

可食部 $100 \mathrm{~g}$ 当たりのエネルギー值を算出する食品 は, 成分表 2015, 「日本食品標準成分表 2015 年版 (七訂) 追補 2016 年」(追補 2016 $)^{11}$, 「日本食品標準成分表 2015 年版（七訂）追補 2017 年 $\rfloor^{12)}($ 追補 2017), 「日本食 品標準成分表 2015 年版（七訂）追補 2018 年」（追補 $2018)^{13}$ にに収載されている食品 2,294 種類（七訂収載食 品）とした。

\section{2. エネルギ一值の算出方法}

\section{1 従来法によるエネルギー值}

従来法によるエネルギー值は，成分表 2015，追補 2016, 追補 2017 打よび追補 2018 のエネルギー収載值(既 収載值）とした。なお,これらの成分表におけるエネル ギー換算係数の個別食品への適用は, 以下の通りである。

(1)穀類, 動物性食品, 油脂類, 大豆抒よび大豆製品の うち主要な食品については, 「日本食品標準成分表 の改訂に関する調查 $\rfloor^{14-17)}$ に基づく係数を適用。
(2)上記以外の食品については，原則として FAO/ $\mathrm{WHO}$ 合同特別専門委員会報告 ${ }^{4}$ のエネルギー換算 係数を適用。

(3)適用すべきエネルギー換算係数が明らかでない食品 については, Atwaterの倸数を適用。

(4)複数の原材料からなる加工食品については, Atwaterの係数を適用。

(5)油いためと野菜類の素揚げについては, 原材料と吸 着した油に対してそれぞれの換算係数を適用。

(6)アルコールを含む食品については, アルコールのエ ネルギー換算係数として $\mathrm{FAO} / \mathrm{WHO}$ 合同特別専門 委員会報告に従い $7.1 \mathrm{kcal} / \mathrm{g}$ を適用。

(7)酢酸を多く含む食品については, 酶酸のエネルギー 換算係数として $3.5 \mathrm{kcal} / \mathrm{g}^{18)}$ を適用。

(8きくいも，こんにゃく，「きのこ類」「藻類」およ び昆布茶は, 四訂成分表占では,「日本人における 利用エネルギー測定調查 ${ }^{19)}$ の結果, 被験者ごとの エネルギー利用率の測定值の変動が大きいこと等か ら, エネルギー換算係数を定めずエネルギー值を算 出しなかった。しかし, 五訂成分表では, エネルギー 值を示すことへの要望が強いことから, 同測定調查 に扔けるたんぱく質, 脂質抒よび炭水化物の成分別 利用率拉よび食品全体としてのエネルギー利用率を 勘案し, 暫定的な対応として Atwater 係数で求めた 值の 0.5 倍值をエネルギー值とした。

2.2 組成に基づく成分值を基礎としたエネルギー值 の算出方法

組成に基づく成分值を基礎としたエネルギー值（組成 エネルギー值）の算出は, 食品成分委員会として合意し た手順に従って, FAO 報告書に準拠した試算エネルギー （kcal）を算出した。手順の概要は次のとおりである。

(1)組成成分值等の正確さの確認抒よび場合分け

組成エネルギー值の基礎となるアミノ酸組成によるた んぱく質, 脂肪酸のトリアシルグリセロール当量, 利用 可能炭水化物, 並びに従来炭水化物の内数としていた食 物繊維と糖アルコール, 抢よび有機酸, アルコールの成 分值等（組成成分值等）は，それぞれ成分分析により求 める成分值となる。組成成分值等については, 他の成分 值に含まれない質量と規定される「差引き法による炭水 化物」が介在しない，それぞれ独立した成分值となるこ とから, 従来は課題とならなかった各成分值に対する測 定不確かさの問題が顕在化する。このため, 各食品にお ける一連の組成成分值等が, エネルギー值の計算上適当 な範囲にあるかどうかについて評価する手順を設けるこ ととした。

具体的には，一連の組成成分值等抒よび水分，灰分等 のその他の一般成分の合計值に対する許容誤差の範囲と して $\pm 5 \%$ を設定し, 合計值がこの範囲内である食品に おいては, 組成成分值等に基づくエネルギー計算を行い, 合計值がこの範囲を逸脱する場合には, 従来の考え方に 
準じて利用可能炭水化物に「差引き」の役割を持たせた エネルギー計算を行う設計とした。具体的には，たんぱ く質抢よび脂質については, 組成による成分值（アミ） 酸組成によるたんぱく質および脂肪酸のトリアシルグリ セロール当量）を優先しつつ, 水分, たんぱく質, 脂質, 利用可能炭水化物, 灰分㧍よびその他の成分の可食部 $100 \mathrm{~g}$ 当たりの質量の合計を求めた。質量の合計が $95 \mathrm{~g}$ 以上 $105 \mathrm{~g}$ 以下の範囲にあり, 分析に基づく成分值の積 算がさ 5\%の誤差に収まると判断される場合 $(\mathrm{G})$ には, 各エネルギー産生成分の成分值にそれぞれのエネルギー 換算係数を乗じる方法を適用した。質量の合計がそれ以 外の場合（NG）には，「組成成分值に基づく利用可能炭 水化物」ではなく, 他の成分值の差引き差分から算出さ れる「差引き法による利用可能炭水化物量」を用いるこ ととし，エネルギー産生成分の成分值にそれぞれのエネ ルギー換算係数を乗じる方法により，エネルギーの計算 を行うよう場合分けをした。

成分值の精度検証のための計算式と, 試算に用いた工 ネルギー換算係数は, 以下の通りである。

(1)-1. 組成成分等の成分值の精度検証のための計算式 組成成分等およびその他の一般成分の合計量 $(\mathrm{g})=$ 水 分+アミノ酸組成によるたんぱく質 ${ }^{*}+$ 脂肪酸のトリ アシルグリセロール当量** + 利用可能炭水化物〈質量〉 + 食物瀻維 + 糖アルコール+酢酸 $+($ 酢酸を除く) 有機 酸+アルコール+灰分 + 硝酸イオン +ポリフェノール +カフェイン+テオブロミン+加熱により発生する二 酸化炭素

*「アミノ酸組成によるたんぱく質」の収載値がな い場合には，「たんぱく質」の収載値を用いる

**「脂肪酸のトリアシルグリセロール当量」の収載 值がない場合には，「脂質」の収載値を用いる

(1)-2. 試算に用いたエネルギー換算係数

原則として, FAO/INFOODS が勧める最新の換算係 数（FAO/INFOODS, 2012）年艺利用した。ただし，特定 の $\left(^{\dagger}\right)$ 糖アルコールおよび有機酸については, 別に定 めた換算係数を利用した。

一アミノ酸組成によるたんぱく質およびたんぱく質：

$17 \mathrm{~kJ} / \mathrm{g}(4 \mathrm{kcal} / \mathrm{g})$

一脂肪酸のトリアシルグリセロール当量および脂質 :

$37 \mathrm{~kJ} / \mathrm{g}(9 \mathrm{kcal} / \mathrm{g})$

一利用可能炭水化物 (単糖当量) $: 16 \mathrm{~kJ} / \mathrm{g}(3.75 \mathrm{kcal} / \mathrm{g}$ )

一差引き法による利用可能炭水化物： $17 \mathrm{~kJ} / \mathrm{g}(4 \mathrm{kcal} / \mathrm{g})$

なお，差引き法による利用可能炭水化物は，次式によ り計算した。

差引き法による利用可能炭水化物 $(\mathrm{g})=100 \mathrm{~g}$ - (アミ ノ酸組成によるたんぱく質 ${ }^{*}+$ 脂肪酸のトリアシルグリ セロール当量 ${ }^{* *}+$ 食物瀻維十糖アルコール +有機酸 + 灰 分十硝酸イオン+ポリフェノール＋カフェイン+テオブ ロミン+加熱により発生する二酸化炭素) の質量 $(\mathrm{g})$

*「アミノ酸組成によるたんぱく質」の収載值がな
い場合には,「たんぱく質」の収載值を用いる **「脂肪酸のトリアシルグリセロール当量」の収載 值がない場合には,「脂質」の収載値を用いる 一食物㵶維 $: 8 \mathrm{~kJ} / \mathrm{g}(2 \mathrm{kcal} / \mathrm{g})$

ーアルコール : $29 \mathrm{~kJ} / \mathrm{g}(7 \mathrm{kcal} / \mathrm{g})$

一 ナソルビトール, $10.8 \mathrm{~kJ} / \mathrm{g}(2.6 \mathrm{kcal} / \mathrm{g})$

一 ${ }^{\dagger}$ マンニトール, $6.7 \mathrm{~kJ} / \mathrm{g}(1.6 \mathrm{kcal} / \mathrm{g})$

一 †ルチトール, $8.8 \mathrm{~kJ} / \mathrm{g}(2.1 \mathrm{kcal} / \mathrm{g})$

一 ${ }^{\dagger}$ (混合物): 還元水あめ, $12.6 \mathrm{~kJ} / \mathrm{g}(3.0 \mathrm{kcal} / \mathrm{g})$

一その他の糖アルコール, $10 \mathrm{~kJ} / \mathrm{g}(2.4 \mathrm{kcal} / \mathrm{g})$

—“酢酸, $14.6 \mathrm{~kJ} / \mathrm{g}(3.5 \mathrm{kcal} / \mathrm{g})$

— ${ }^{\dagger}$ 乳酸, $15.1 \mathrm{~kJ} / \mathrm{g}(3.6 \mathrm{kcal} / \mathrm{g})$

— クエン酸, $10.3 \mathrm{~kJ} / \mathrm{g}(2.5 \mathrm{kcal} / \mathrm{g})$

— †リンゴ酸, $10.0 \mathrm{~kJ} / \mathrm{g}(2.4 \mathrm{kcal} / \mathrm{g})$

一その他の有機酸, $13 \mathrm{~kJ} / \mathrm{g}(3 \mathrm{kcal} / \mathrm{g})$

(2)成分の合計值が $100 \mathrm{~g} \pm 5 \mathrm{~g}$ の範囲内となる場合

たんぱく質, 脂質, 炭水化物については, 原則として, それぞれの組成に基づく成分值を用い，その他のエネル ギー産生成分である食物纎維, 糖アルコール, 有機酸お よびアルコールとともに, 成分ごとに規定のエネルギー 換算係数を乗じ, 合計して, 全体のエネルギーを計算し た。なお，日本食品標準成分表では，エネルギー計算に ついては FAO のガイダンスに従い $\mathrm{kJ}$ 単位と $\mathrm{kcal}$ 単位 の 2 つの数值を求めるが, 本稿では紙幅の都合上 $\mathrm{kcal}$ 単位の計算例のみを示すこととした。計算式は, 以下の 通りである。

(2)-1. 計算式 (kcal 単位への換算の場合)

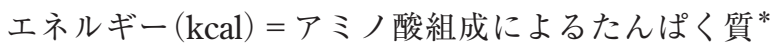
$(\mathrm{g}) \times 4 \mathrm{kcal} / \mathrm{g}+$ 脂肪酸のトリアシルグリセロール当 量** $(\mathrm{g}) \times 9 \mathrm{kcal} / \mathrm{g}+$ 利用可能炭水化物〈単糖当量〉 ${ }^{* * *}$ $(\mathrm{g}) \times 3.75 \mathrm{kcal} / \mathrm{g}+$ 食物瀻維 $(\mathrm{g}) \times 2 \mathrm{kcal} / \mathrm{g}+$ ソルビトー ル $(\mathrm{g}) \times 2.6 \mathrm{kcal} / \mathrm{g}+$ マンニトール $(\mathrm{g}) \times 1.6 \mathrm{kcal} / \mathrm{g}+$ マ ルチトール $(\mathrm{g}) \times 2.1 \mathrm{kcal} / \mathrm{g}+$ 還元水あめ $(\mathrm{g}) \times 3.0$ $\mathrm{kcal} / \mathrm{g}+$ その他の糖アルコール $\times 2.4 \mathrm{kcal} / \mathrm{g}+$ 酢酸 $(\mathrm{g})$ $\times 3.5 \mathrm{kcal} / \mathrm{g}+$ 乳酸 $(\mathrm{g}) \times 3.6 \mathrm{kcal} / \mathrm{g}+$ クエン酸 $(\mathrm{g}) \times 2.5$ $\mathrm{kcal} / \mathrm{g}+$ リンゴ酸 $(\mathrm{g}) \times 2.4 \mathrm{kcal} / \mathrm{g}+$ その他の有機酸 $(\mathrm{g}) \times 3 \mathrm{kcal} / \mathrm{g}+$ アルコール $(\mathrm{g}) \times 7 \mathrm{kcal} / \mathrm{g}$

*「アミノ酸組成によるたんぱく質」の収載值がな い場合には「たんぱく質」の収載值を用いる

**「脂肪酸のトリアシルグリセロール当量」の収載 值がない場合には「脂質」の収載值を用いる

***「利用可能炭水化物〈単糖当量〉」の収載值がな い場合には「差引き法による利用可能炭水化物」 の収載值を用いる。その場合, エネルギー換算係 数は $17 \mathrm{~kJ} / \mathrm{g}$ あるいは $4 \mathrm{kcal} / \mathrm{g}$ を用いる

(3)成分の合計值が $100 \mathrm{~g} \pm 5 \mathrm{~g}$ から外れる場合

たんぱく質および脂質は原則として組成に基づく成分 值を用い, 利用可能炭水化物を代替する成分として, 差 引き法による利用可能炭水化物を用いて, それぞれの工 ネルギー換算係数を乗じた。さらに，他のエネルギー産 
生成分 (食物繊維, 糖アルコール, 有機酸およびアルコー ル）のエネルギー值と合計して, 全体のエネルギーを計 算した。計算式は以下の通りである。

(3)-1. 計算式（kcal 単位への換算の場合） エネルギー $(\mathrm{kcal})=$ アミノ酸組成によるたんぱく質* $(\mathrm{g}) \times 4 \mathrm{kcal} / \mathrm{g}+$ 脂肪酸のトリアシルグリセロール当 量 ${ }^{* *}(\mathrm{~g}) \times 9 \mathrm{kcal} / \mathrm{g}+$ 差引き法による利用可能炭水化 物 $(\mathrm{g}) \times 4 \mathrm{kcal} / \mathrm{g}+$ 食物絒維 $(\mathrm{g}) \times 2 \mathrm{kcal} / \mathrm{g}+$ ソルビトー ル $(\mathrm{g}) \times 2.6 \mathrm{kcal} / \mathrm{g}+$ マンニトール $(\mathrm{g}) \times 1.6 \mathrm{kcal} / \mathrm{g}+$ マ ルチトール $(\mathrm{g}) \times 2.1 \mathrm{kcal} / \mathrm{g}+$ 還元水あめ $(\mathrm{g}) \times 3.0$ $\mathrm{kcal} / \mathrm{g}+$ その他の糖アルコール $\times 2.4 \mathrm{kcal} / \mathrm{g}+$ 酢酸 $(\mathrm{g})$ $\times 3.5 \mathrm{kcal} / \mathrm{g}+$ 乳酸 $(\mathrm{g}) \times 3.6 \mathrm{kcal} / \mathrm{g}+$ クエン酸 $(\mathrm{g}) \times 2.5$ $\mathrm{kcal} / \mathrm{g}+$ リンゴ酸 $(\mathrm{g}) \times 2.4 \mathrm{kcal} / \mathrm{g}+$ その他の有機酸 $(\mathrm{g}) \times 3 \mathrm{kcal} / \mathrm{g}+$ アルコール $(\mathrm{g}) \times 7 \mathrm{kcal} / \mathrm{g}$

*「アミノ酸組成によるたんぱく質」の収載值がな い場合には「たんぱく質」の収載值を用いる

**「脂肪酸のトリアシルグリセロール当量」の収載 值がない場合には「脂質」の収載值を用いる

\section{3. 組成エネルギ一值と既収載エネルギ一值の比較}

組成エネルギー值の算出方法の(2)又は(3)の手順で算出 した食品ごとのエネルギー值（kcal）を既収載值と比較 した。比較指標として, 両者の相違量（組成エネルギー 值－既収載值）および一致率（組成エネルギー值 $\div$ 既収 載エネルギー值 $\times 100(\%))$ を算出した。

\section{4. 国民健康・栄養調査を用いたエネルギー摂取量の 比較}

平成 26 年国民健康・栄養調査の基礎データ ${ }^{21)}$ から, 調查票に出現する日本食品標準成分表収載食品 $(1,362$ 食品）の食品別摂取重量の人日当たり平均值を求めた。 この人日摂取量に, 新たに算出した組成エネルギー值 $(\mathrm{kcal} / 100 \mathrm{~g})$ と既収載值 $(\mathrm{kcal} / 100 \mathrm{~g})$ をそれぞれ用いて, 個々の食品から摂取する人日当たりエネルギー量 ( $\mathrm{kcal} / 1$ 人日) を算出し, さらに一致率（組成エネルギー 值 $\div$ 既収載值 $\times 100$ ）を算出した。また，すべての食品 からのエネルギー摂取量を合計して 1 日の総エネルギー 摂取量を算出し，両者の一致率を算出した。なお，国民 健康・栄養調查では, 日本食品標準成分表を用いない独 自の食品がある。そのため, 日本食品標準成分表に収載 されている食品からのエネルギー摂取量 (A) と, 国民 健康・栄養調查のエネルギー摂取量（独自の食品のエネ ルギー量も加味された值；B）を用いて, 組成エネルギー 值から算出した值（C）が1日のエネルギーに達するよ うに，B/A を係数としてCに乗じ, 組成エネルギー值 による1日当たりの摂取量を算出した。

\section{結}

\section{果}

\section{1. 食品の組成エネルギ一值}

表 1 に食品群別の組成エネルギー値, 既収載値, 両者 の相違量抢よび一致率について, 平均值と標準偏差を示 した。また，全食品についてのこれらの值も示した。
食品群別の可食部 $100 \mathrm{~g}$ 当たりのエネルギー值を比較 すると, 組成エネルギー值では, 最大の油脂類で $843 \pm$ $79 \mathrm{kcal}$, 最小の野菜類で $40 \pm 51 \mathrm{kcal}$ であり, 全 2,294 食品の平均值は $183 \pm 167 \mathrm{kcal}$ であった。既収載值で同 様の数值を見ると, 油脂類が $887 \pm 76 \mathrm{kcal}$, 野菜類が 48 $\pm 53 \mathrm{kcal}$ であり, 全食品の平均值は $195 \pm 173 \mathrm{kcal}$ で あった。食品群別のエネルギー值を多い順に並べると, エネルギー值の近接している卵類と乳類以外では, 食品 群間の順列に変化はなかった。また, 食品毎の新旧エネ ルギー值の一致率 (100\%が同值) でみると, Atwater 係数の 0.5 倍としていた暫定措置の影響を外すこととな る藻類の值が $126 \pm 24 \%$ となった。一方, 差引き炭水化 物中の食物繊維の比率の高い野菜類では, 最小の $76 \pm$ $20 \%$ となった。なお，全 2,294 食品の一致率の平均値は $91 \pm 17 \%$ であった。一致率が $100 \%$ 未満の食品群は 14 群であり, $100 \%$ 以上の食品群は 4 群（砂糖および甘味 類, きのこ類, 藻類および果実類) であった。また, い もおよびでんぷん類, 種実類, 調理加工品類は $99 \%$ で ある一方で, 動物性食品の魚介類, 肉類, 卵類, 乳類は, 80-93\%と低い值を示した。

表 2 に各食品群別の組成エネルギー值と既収載値の一 致率について, 最大值とその食品, 最小值とその食品を 示した。食品群別の一致率の最大と最小の差は, 最大 $181 \%$ (し好飲料類), 最小 $7 \%$ (調理加工食品類) であり, 全食品では最大 $189 \%$ (きくいも生), 最小 $4 \%$ （麦茶浸 出液）であった。

図 1 に, 組成エネルギー值と既収載值の一致率をヒス トグラムで示した。一致率 80-100\%の範囲に 1,559 食品 （対象食品の $68 \%$ ）が含まれ，ついで一致率 60-80\%に 304 食品（対象食品の $13 \%$ ）が，一致率 100-120\%に 268 食品（対象食品の $12 \%$ ）が含まれていた。

\section{2. 国民健康・栄養調査を用いた摂取エネルギ一量の 比較}

平成 26 年国民健康・栄養調查の基礎データの食品別 摂取量と, 七訂収載食品のエネルギー値を用いて算出し た総エネルギー摂取量は $1,641 \mathrm{kcal} /$ 日であり, 平成 26 年国民健康・栄養調查の 1 日成人 1 人当たりの全世代の エネルギー搔取量の平均值は， $1,897 \mathrm{kcal} /$ 日であった。 方法に記載したように, 組成エネルギー值および既収載 值の計算にこの係数を乗じて, エネルギー摂取量を補正 した。表 $3 に$ にここれらを食品群別エネルギー撖取量およ び総エネルギー摂取量として示した。また，2つの方法 により算出したエネルギー拃取量の一致率も示した。

2 つのエネルギー㠌取量の相違量の絶対值が最も大き

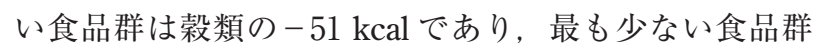
は砂糖及び甘味類, 種実類, 果実類, きのこ類の $0 \mathrm{kcal}$ であった。一致率をみると, きのこ類および藻類は, 組 成エネルギー值が既収載値に比べ高い值となる傾向があ るが, 摂取量が少ないためエネルギー摂取量としては 2 つ方法での相違は少なかった。砂糖および甘味類, 種害 
表 1 食品群別組成エネルギー值と既収載の相違

\begin{tabular}{|c|c|c|c|c|c|}
\hline \multirow{2}{*}{ 食品数 } & & \multicolumn{2}{|c|}{ エネルギー（kcal/100 g） } & \multirow{2}{*}{$\frac{\text { 相違量（kcal） }}{(\mathrm{a}-\mathrm{b})}$} & \multirow{2}{*}{$\frac{\text { 一致率（\%) }}{(\mathrm{a} / \mathrm{b} \times 100)}$} \\
\hline & & 組成值（a） & 既収載值（b） & & \\
\hline 穀類 & 平均 & 272 & 285 & -13 & 95 \\
\hline 166 & 標準偏差 & 113 & 116 & 9 & 4 \\
\hline \multirow[t]{2}{*}{ いも及びでん粉類 } & 平均 & 150 & 153 & -3 & 99 \\
\hline & 標準偏差 & 117 & 115 & 10 & 17 \\
\hline \multirow[t]{2}{*}{ 砂糖及び甘味類 } & 平均 & 345 & 336 & 9 & 103 \\
\hline & 標準偏差 & 53 & 55 & 7 & 3 \\
\hline \multirow{2}{*}{ 豆類 } & 平均 & 238 & 261 & -23 & 90 \\
\hline & 標準偏差 & 124 & 132 & 16 & 6 \\
\hline \multirow[t]{2}{*}{ 種実類 } & 平均 & 495 & 495 & 1 & 99 \\
\hline & 標準偏差 & 208 & 197 & 22 & 5 \\
\hline \multirow[t]{2}{*}{ 野菜類 } & 平均 & 40 & 48 & -8 & 76 \\
\hline & 標準偏差 & 51 & 53 & 8 & 20 \\
\hline \multirow[t]{2}{*}{ 果実類 } & 平均 & 82 & 83 & -1 & 99 \\
\hline & 標準偏差 & 77 & 77 & 8 & 14 \\
\hline \multirow[t]{2}{*}{ きのこ類 } & 平均 & 58 & 51 & 7 & 118 \\
\hline & 標準偏差 & 69 & 59 & 19 & 22 \\
\hline \multirow{2}{*}{ 藻類 } & 平均 & 125 & 94 & 31 & 126 \\
\hline & 標準偏差 & 100 & 76 & 39 & 24 \\
\hline \multirow[t]{2}{*}{ 魚介類 } & 平均 & 151 & 170 & -19 & 87 \\
\hline & 標準偏差 & 87 & 92 & 12 & 9 \\
\hline \multirow[t]{2}{*}{ 肉類 } & 平均 & 250 & 279 & -30 & 88 \\
\hline & 標準偏差 & 157 & 167 & 15 & 6 \\
\hline \multirow[t]{2}{*}{ 卵類 } & 平均 & 211 & 243 & -32 & 85 \\
\hline & 標準偏差 & 162 & 178 & 19 & 5 \\
\hline \multirow[t]{2}{*}{ 乳類 } & 平均 & 229 & 242 & -13 & 94 \\
\hline & 標準偏差 & 150 & 158 & 13 & 4 \\
\hline \multirow[t]{2}{*}{ 油脂類 } & 平均 & 843 & 887 & -45 & 95 \\
\hline & 標準偏差 & 79 & 76 & 12 & 2 \\
\hline \multirow[t]{2}{*}{ 菓子類 } & 平均 & 322 & 330 & -8 & 97 \\
\hline & 標準偏差 & 116 & 118 & 7 & 3 \\
\hline \multirow[t]{2}{*}{ し好飲料類 } & 平均 & 131 & 139 & -8 & 88 \\
\hline & 標準偏差 & 113 & 118 & 31 & 27 \\
\hline 調味料及び香辛料類 & 平均 & 182 & 188 & -6 & 92 \\
\hline 144 & 標準偏差 & 158 & 162 & 10 & 18 \\
\hline \multirow[t]{2}{*}{ 調理加工食品類 } & 平均 & 208 & 209 & -2 & 99 \\
\hline & 標準偏差 & 81 & 81 & 3 & 2 \\
\hline \multirow[t]{2}{*}{ 全食品 } & 平均 & 183 & 195 & -12 & 91 \\
\hline & 標準偏差 & 167 & 173 & 19 & 17 \\
\hline
\end{tabular}

類, 果実類, きのこ類, 藻類を除く食品群は, 組成エネ ルギー值に基づくエネルギー攝取量は, 既収載值に基づ くエネルギー摂取量に比べ小さな值となることがわかっ た。その結果, 1 人 1 日当たりの総エネルギー摂取量は,
組成エネルギー值を用いた場合は，既収載値を用いた場 合に比べ，8\%程度低い值になることがわかった。

図 2 に, 平成 26 年国民健康・栄養調査の基礎デー夕 に出現する食品の新旧エネルギー值の一致率のヒストグ 
表 2 組成エネルギー值と既収載の一致率（最大值とその食品, 最小值とその食品）

\begin{tabular}{|c|c|c|c|c|c|c|c|c|}
\hline \multirow[b]{2}{*}{ 食品群 } & \multicolumn{4}{|c|}{ 最大值の食品 } & \multicolumn{4}{|c|}{ 最小值の食品 } \\
\hline & $\begin{array}{c}\text { 一致率 } \\
(\%)\end{array}$ & $\begin{array}{c}\text { 差 } \\
(\mathrm{kcal} / 100 \mathrm{~g})\end{array}$ & $\begin{array}{l}\text { 食品 } \\
\text { 番号 }\end{array}$ & 食品名 & $\begin{array}{c}\text { 一致率 } \\
(\%)\end{array}$ & $\begin{array}{c}\text { 差 } \\
(\mathrm{kcal} / 100 \mathrm{~g})\end{array}$ & $\begin{array}{l}\text { 食品 } \\
\text { 番号 }\end{array}$ & 食品名 \\
\hline 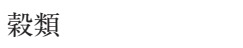 & 103 & 10 & 1013 & フランスパン & 82 & -20 & 1072 & 小麦たんぱく＼cjkstart粒状 \\
\hline いも及びでん粉類 & 189 & 31 & 2001 & きくいも 塊茎 生 & 74 & -18 & 2063 & じゃがいも 塊茎 皮つき 生 \\
\hline 砂糖及び甘味類 & 109 & 24 & 3028 & 異性化液糖＼cjkstart高果糖液糖 & 99 & -4 & 3001 & 黒砂糖 \\
\hline 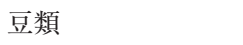 & 101 & 5 & 4030 & きな粉 脱皮大豆 黄大豆 & 69 & -34 & 4051 & おから 生 \\
\hline 種実類 & 106 & 34 & 5045 & らっかせい いり 小粒種 & 89 & -15 & 5043 & はす 成熟 ゆで \\
\hline 野菜類 & 127 & 4 & 6237 & パクチョイ 葉 生 & 14 & -10 & 6368 & だいこん 生 おろし汁 \\
\hline 果実類 & 157 & 11 & 7157 & ココナッツウォーター & 36 & -25 & 7169 & グァバ 白肉種 生 \\
\hline きのこ類 & 169 & 16 & 8024 & うすひらたけ 生 & 86 & -3 & 8001 & えのきたけ 生 \\
\hline 藻類 & 175 & 83 & 9022 & 塩昆布 & 80 & 0 & 9026 & てんぐさ ところてん \\
\hline 魚介類 & 102 & 4 & 10048 & まいわし＼cjkstart水煮 & 52 & -18 & 10306 & はまぐり＼cjkstart生 \\
\hline 肉類 & 100 & -1 & 11293 & にわとり つくね & 72 & -31 & 11232 & にわとり肝臓＼cjkstart生 \\
\hline 卵類 & 94 & -19 & 12012 & 鷄卵 卵黄 加糖卵黄 & 79 & -38 & 12001 & うこっけい卵 全卵 生 \\
\hline 乳類 & 101 & 3 & 13050 & チーズホエーパウダー & 87 & -5 & 13054 & ヨーグルト 無脂肪無糖 \\
\hline 油脂類 & 98 & -22 & 14011 & ひまわり油 ハイリノール & 91 & -57 & 14021 & ファットスプレッド \\
\hline 菓子類 & 102 & 2 & 15122 & くずもち 小麦でん粉製品 & 83 & -15 & 15087 & ゼリー オレンジ \\
\hline 乙好飲料類 & 185 & 81 & 16051 & 昆布茶 & 4 & -1 & 16055 & 麦茶 浸出液 \\
\hline 調味料及び香辛料類 & 130 & 0 & 17023 & 煮干しだし & 10 & -4 & 17022 & しいたけだし \\
\hline 調理加工食品類 & 100 & 0 & 18011 & シチュービーフ レトルトパウチ & 93 & -13 & 18023 & 松前漬け しょうゆ漬 \\
\hline
\end{tabular}

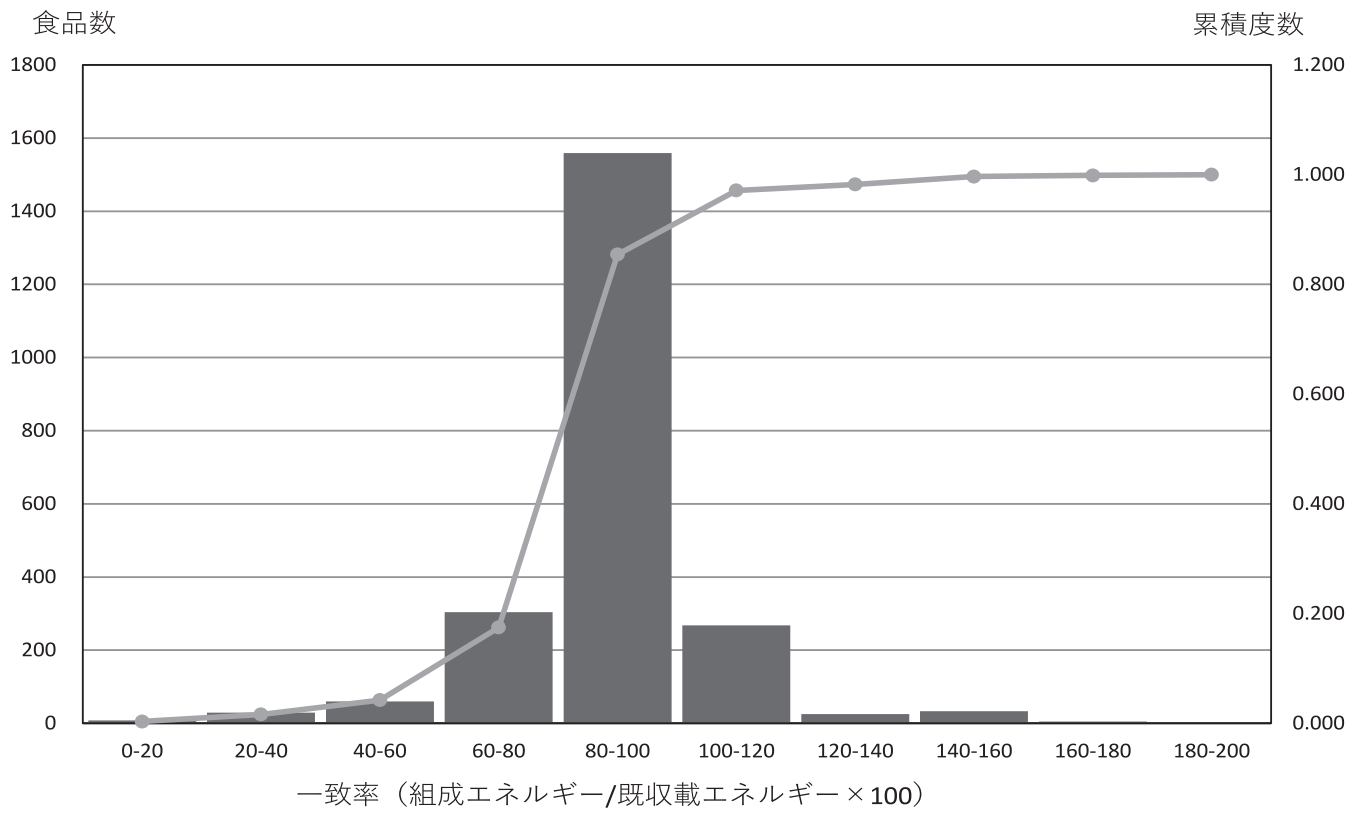

図 1 組成エネルギー值と既収載值の一致率の度数分布（全食品）

ラムを示した。この分布は, 実生活で利用する頻度の高 い約 1,400 食品を対象とするものとなるが，総じて分布 の形状は図 1 と相同性の高いものとなった。一致率 80$100 \%$ 範囲に 924 食品（対象食品の $68 \%$ ）が含まれ, ついで一致率 60-80\%に 192 食品（対象食品の 14\%）が, 一致率 100-120\%に 142 食品（対象食品の 10\%）が含ま れていた。

個々の食品について組成エネルギー值を用いたエネル ギー摂取量と既収載值を用いたエネルギー摂取量の相違 量 [(組成エネルギー值によるエネルギー摂取量 $)-$ (既 収載值によるエネルギー摂取量) ]をみると,「水稲めし, 精白米, うるち米」の相違量がー $36 \mathrm{kcal}$ と絶対值が最
大となり, 以下「全卵, 生」,「じゃがいも, 塊茎, 皮な し, 生」,「発泡酒」, 「普通牛乳」,「ビール, 淡色」, 「調 合油」, 「若鶏肉, もも, 皮つき, 生」が, $-10--2 \mathrm{kcal}$ の值を示した。一方,「甘がき, 生」,「バナナ, 生」に おいて約 $0.7 \mathrm{kcal}$ 高い值を示した。

\section{考察}

\section{1. 七訂収載食品ごとの組成エネルギ一值}

可食部 $100 \mathrm{~g}$ 当たりの組成エネルギー值と既収載值と の食品群別エネルギー值の一致率は, 最大 $126 \pm 24 \%$ (藻 類）から最小 $76 \pm 20 \%$ （野菜類）の範囲にあり, 食品 群により相違があった。また, 藻類, きのこ類の組成エ 
表 3 国民健康・栄養調査に基づく 1 日当たりのエネルギー摂取量

\begin{tabular}{|c|c|c|c|c|c|}
\hline \multirow{2}{*}{ 食品群 } & \multirow{2}{*}{$\begin{array}{l}\text { 出現 } \\
\text { 食品数 }\end{array}$} & \multicolumn{2}{|c|}{ 摂取エネルギー（kcal/日） } & \multirow{2}{*}{$\begin{array}{l}\text { 相違量 } \\
\text { (kcal) }\end{array}$} & \multirow{2}{*}{$\begin{array}{c}\text { 一致率 } \\
(\%)\end{array}$} \\
\hline & & 組成值 & 既収載值 & & \\
\hline 穀類 & 98 & 683 & 734 & -51 & 93 \\
\hline いも及びでん粉類 & 32 & 42 & 48 & -6 & 87 \\
\hline 砂糖及び甘味類 & 13 & 7 & 6 & 0 & 103 \\
\hline 豆類 & 56 & 93 & 99 & -7 & 93 \\
\hline 種実類 & 28 & 10 & 10 & 0 & 101 \\
\hline 野菜類 & 248 & 71 & 83 & -11 & 86 \\
\hline 果実類 & 110 & 62 & 62 & 0 & 100 \\
\hline きのこ類 & 28 & 3.4 & 3.0 & 0 & 113 \\
\hline 藻類 & 36 & 3.3 & 2.7 & 1 & 123 \\
\hline 魚介類 & 274 & 77 & 86 & -9 & 89 \\
\hline 肉類 & 124 & 207 & 231 & -24 & 90 \\
\hline 卵類 & 11 & 43 & 54 & -11 & 80 \\
\hline 乳類 & 47 & 83 & 90 & -7 & 93 \\
\hline 油脂類 & 20 & 90 & 95 & -5 & 95 \\
\hline 菓子類 & 108 & 89 & 92 & -3 & 97 \\
\hline し好飲料類 & 46 & 65 & 79 & -14 & 82 \\
\hline 調味料及び香辛料類 & 83 & 91 & 95 & -3 & 96 \\
\hline 全食品 & 1,362 & 1,719 & 1,868 & -149 & 92 \\
\hline
\end{tabular}

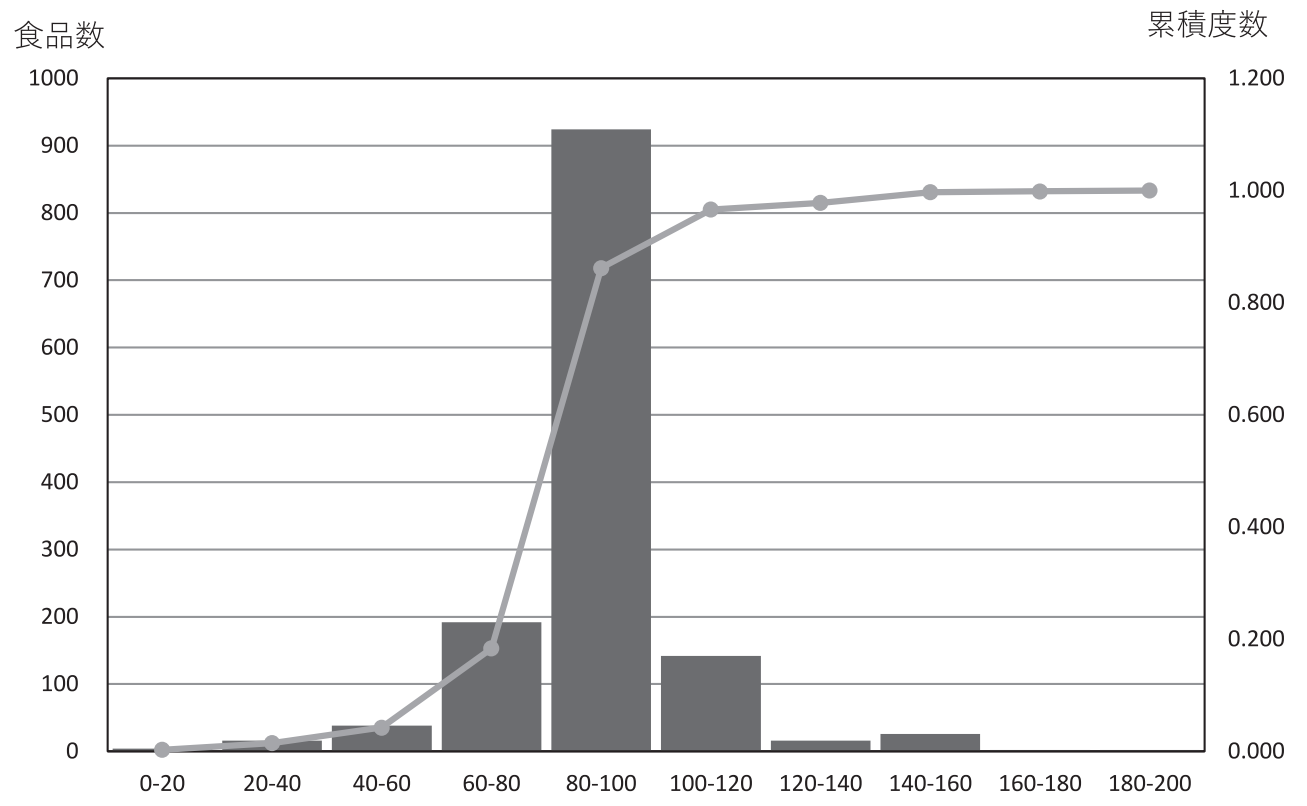

図 2 国民健康・栄養調查において日摄取量データのある 1,362 食品のエネルギー值一致率の度数分布

ネルギー值は既収載值よりも高く，野菜類，肉類の組成 エネルギー值は既収載值よりも低かった。組成エネル ギー值は，既収載值よりもエネルギー摂取量に近似した 值であることから，これからの栄養価計算ではエネル ギー值の算出に組成エネルギー值を用いることが望まし いと考えられた。

また，全食品のエネルギー值の一致率が $91 \pm 17 \%$ で あったことから，日本人が各食品群を等しく摂取し，食 品群のすべての食品を均等に摂取したと仮定すれば，既 収載値で算出したエネルギー量よりも，約 $9 \%$ 少ないエ
ネルギー量を摂取したと考えられる。

一致率が $100 \%$ 未満（既収載值よりも組成エネルギー 值が低い場合）の食品群は 14 群であった。摂取量が多 い野菜類, 動物性食品の魚介類, 肉類および卵類の一致 率は，76-88\%と低い值を示した。これらの食品群は, 食事の主菜および副菜に相当するため摂取量が多い食品 群である。そのため，これらの食品群の組成エネルギー 值が既収載值よりも低いことは, 総エネルギー摂取量に 与える影響が大きいと考えられる。一方，果実類，いも およびでんぷん類, 種実類, 調理加工品類は, 組成エネ 
ルギー值と既収載值がほぼ等しい食品群であることがわ かった。

各食品群別の組成エネルギー值と既収載值の一致率の 最大值と最小值とその食品抢よび両者の差をみると, 一 致率の幅が大きい食品群（野菜類）や小さい食品群（乳 類および調理加工食品類）があることがわかった。一致 率が 80-100\%の範囲に 1,559 食品（対象食品の $68 \%$ ) が含まれ，ついで一致率 60-80\%に 304 食品（対象食品 の $13 \%$ ）が，一致率 100-120\%に 268 食品（対象食品の 12\%）が含まれていた。

組成エネルギー值が既収載值に比べ増減した食品に は, 増減した理由がある。増加した食品をみると, 例え ば，きのこや藻類は，既収載值の算出方法（成分表 2015 のエネルギー計算) において, Atwater 係数により 算出したエネルギーの 0.5 倍值を暫定的に用いたものだ が, 組成エネルギー值の算出方法では, 食物纎維等に特 定の換算係数を用いて計算したことの影響である。また, ココアは, 従来適用していた FAO の換算係数が特異的 に低く設定されているため, 食品別のエネルギー換算倸 数を適用しなくなったことに伴い増加したためである。 一方, 組成エネルギー值が最も小さい值に変化した食品 をみると, せん茶 (茶葉) は, 炭水化物の大部分を占め る食物繊維に対する換算係数を使用したためである。

また，これらの全食品を通じたエネルギー計算方法の 相違点として, 組成エネルギー值の計算では, 従来は差 引き炭水化物の内数であった, 糖アルコール, 食物繊維, 酥酸以外の有機酸について, それぞれの化合物の消化性 に見合ったより低いエネルギー産生率を適用したこと と, ケルダール窒素から推定していた従来のたんぱく質 に, 未知の窒素化合物が混在することで, 従来法のエネ ルギー值が, アミノ酸組成から算出する值よりも高く計 算されていた可能性があることが主な要因である。

このように, 食品の成分構成の特徴に応じて, 新旧の エネルギー值の一致率は変化する。したがって, 特に複 数の食品からなる食事の栄養価計算の場合では, 組成工 ネルギー值を用いる栄養価計算結果を, 既収載值を用い た栄養価計算結果と比較することは, 数值の評価が困難 なため，好ましくないことがわかった。

2. 国民健康・栄養調査結果を用いたエネルギー摂取 量の比較

平成 26 年国民健康・栄養調査の基礎デー夕を用いて, 組成エネルギー值によるエネルギー摂取量および既収載 值によるエネルギー㠌取量（1 日当たりの食品群打よび 総摂取量）扔よび両者の一致率を算出した。可食部 100 $\mathrm{g}$ 当たりのエネルギー值の一致率が低いきのこ類および 藻類は, 摂取重量が少ないためエネルギー摂取量の相違 は少なかった。可食部 $100 \mathrm{~g}$ 当たりのエネルギー值の一 致率が 99-100\%であった果実類, 種実類のエネルギー 摂取量の一致率は，それぞれ $100 \%$ と $101 \%$ であった。 いも㧍よびでんぷん類のエネルギー摂取量の一致率が
87\%と小さくなったことは, 国民健康・栄養調査で摂取 した個々の食品の一致率が低い值であったためと推察さ れる。穀類, 野菜類, 動物性食品の魚介類, 肉類, 卵類, 乳類のエネルギー㠌取量の一致率は, 80-93\%と低い值 を示した。穀類は, 可食部 $100 \mathrm{~g}$ 当たりのエネルギー值 の一致率よりも低い值になった。このことは, 主食の飯 (うるち精白米: 可食部 $100 \mathrm{~g}$ 当たりのエネルギー值の 一致率 $92 \%$ ）の摂取量が多いため, 穀類全体のエネル ギー摂取量に影響したためと考えられる。

組成エネルギー值を用いた場合の総エネルギー摂取量 は, 既収載值を用いた場合に比べ，8\%程度低い值にな ることが分かった。このことは, 可食部 $100 \mathrm{~g}$ 当たりの エネルギー值の結果（全食品単純平均で $9 \%$ の低減）と 近似しているが，1\%だけ低減が解消されている。日本 人は, 日本食品標準成分表の全収載食品を単純に平均的 に食べないものの, ほほ均等に食べていると考えられる。 今回の解析で用いた食品拉よび撕取量は, 平成 26 年 国民健康・栄養調查に基づくものである。しかし, 既収 載值よりも組成エネルギー值が大きい食品群（砂糖およ び甘味類, きのこ類, 藻類) と, 既収載值よりも組成工 ネルギー值が小さい食品群 (魚介類, 肉類, 卵類, 乳類 など）の摂取量に片寄りがあると，両者から算出したエ ネルギー摂取量の相違は大きくなる。

これらのことから, 既収載值で算出した日本人のエネ ルギー摂取量は, 実際のエネルギー摃取量に近似したエ ネルギー量（組成エネルギー值によるエネルギー量）に 比べ, $8 \%$ 程度多いと考えられる。したがって, 今後, 食品からのエネルギー摂取量を評価する場合には, 根拠 とした日本食品標準成分表の改訂年次を確認して, 同じ エネルギー計算の方法を用いた值同士で比較するよう， 留意する必要がある。

なお, 本稿は成分表の次期改訂に向けたシミュレー ションとして実施したものであり，2018 年末現在の七 訂成分值に基づいている。2020 年 12 月公表予定の「日 本食品標準成分表 2020 (八訂)」(仮称) の成分值や, エネルギー計算の細部手順については, 公表された成分 表の解説を参照頂きたい。

\section{利 益 相 反}

本論文の合評内容に関連して申告すべき COI 状態は ない。

本稿の執筆の機会を頂いた公益社団法人日本栄養・食 糧学会会長加藤久典博士に感謝申し上げます。また, 日 本食品標準成分表の検証のための資料を提供頂いた厚生 労働省健康局総務課栄養指導室, 本検証内容を共に検討 した科学技術・学術審議会資源調查分科会食品成分委員 会㧍よび文部科学省科学技術・学術政策局政策課資源室 の皆様に感謝いたします。 


\section{文献}

1）文部科学省科学技術 - 学術審議会資源調查分科会編 （2015）日本食品標準成分表 2015 年版（七訂），全 国官報販売協同組合，東京.

2) Atwater WO (1910) Principles of nutrition and nutritive value of foods, United States Department of Agriculture. Farmers' Bulletin. No. 142, p. 10-2.

3) FAO/WHO (1973) Energy and protein requirements, Report of a Joint FAO/WHO Ad Hoc Expert Committee. WHO Technical Report Series, No. 522; FAO Nutrition Meetings Report Series. No. 52.

4) Food and Agriculture Organization of the United Nations (2003) Food energy - methods of analysis and conversion factors, Report of a technical workshop, FAO Food and Nutrition paper 77, p. 3-6.

5）科学技術庁資源調查分編（1982）四訂日本食品標準 成分表. 大蔵省印刷局，東京.

6）科学技術庁資源調查会編（2000）五訂日本食品標準 成分表. 大蔵省印刷局, 東京.

7）消費者庁. 食品表示基準について (新旧対照表). https://www.caa.go.jp/policies/policy/food_labeling/ food_labeling_act/pdf/food_labeling_cms101_200327_ 14.pdf\#search（2020 年 9 月 2 日閲覧）。

8）文部科学省科学技術・学術審議会資源調査分科会編 （2015）日本食品標準成分表 2015 年版（七訂）アミ ノ酸成分表編. 全国官報販売協同組合, 東京.

9）文部科学省科学技術 - 学術審議会資源調查分科会編 （2015）日本食品標準成分表 2015 年版（七訂）脂肪 酸成分表編. 全国官報販売協同組合, 東京.

10）文部科学省科学技術・学術審議会資源調査分科会編 （2015）日本食品標準成分表 2015 年版（七訂）炭水 化物成分表編一利用可能炭水化物, 糖アルコール及 び有機酸一. 全国官報販売協同組合, 東京.

11）文部科学省科学技術・学術審議会資源調查分科会編 （2016）日本食品標準成分表 2015 年版（七訂）追補 2016 年. 全国官報販売協同組合，東京.

12）文部科学省科学技術・学術審議会資源調查分科会編
（2017）日本食品標準成分表 2015 年版（七訂）追補 2017 年. 全国官報販売協同組合, 東京.

13）文部科学省科学技術・学術審議会資源調査分科会編 （2018）2015 年版（七訂）追補 2018 年. 全国官報 販売協同組合, 東京.

14）科学技術庁資源調查会編（1979）日本食品標準成分 表の改訂に関する調查資料一日本人における大豆及 び大豆製品の利用エネルギー測定調查結果一, 科学 技術庁資源調査所資料第 70 号. 科学技術庁資源調 查所, 東京.

15）科学技術庁資源調查会編（1980）日本食品標準成分 表の改訂に関する調查資料一日本人に扔ける動物性 食品の利用エネルギー測定調查結果一. 科学技術庁 資源調所資料第 73 号. 科学技術庁資源調查所, 東京.

16）科学技術庁資源調查会編（1981）日本食品標準成分 表の改訂に関する調查資料一日本人に扔ける穀類の 利用エネルギー測定調查結果一. 科学技術庁資源調 查所資料第 92 号. 科学技術庁資源調查所, 東京.

17）科学技術庁資源調查会編（1982）日本食品標準成分 表の改訂に関する調查資料一日本人における油脂類 の利用エネルギー測定調査結果及び主要食品の利用 エネルギー值一．科学技術庁資源調查所資料第 99 号. 科学技術庁資源調查所, 東京.

18) Merrill AL, Watt BK (1955) Energy value of foods - basis and derivation - Agricultural Research Service United States Department of Agriculture. Agriculture Handbook. No. 74 .

19）科学技術庁資源調查会編（1980）日本食品標準成分 表の改訂に関する調査資料一日本人における藻類及 びきのこ類の利用エネルギー測定調查結果一. 科学 技術庁資源調查所資料第 82 号. 科学技術庁資源調 查所, 東京.

20) FAO/INFOODS (2012) Guidelines for Checking Food Composition Data prior to the Publication of a User Table/Database, Version 1.0.

21）厚生労働省健康局健康課栄養指導室（2015）平成 26 年度国民健康・栄養調查の基礎資料，東京. 


\title{
Lecture
}

\section{Comparison of Energy Values on Composition-based Method and Conventional Method}

\author{
Masato Matsumoto, ${ }^{1}$ Tomoko Watanabe, ${ }^{*, 2,3}$ Shinji Matsumoto, ${ }^{1}$ and Akemi Yasui ${ }^{2,4}$
}

(Received September 21, 2020; Accepted October 16, 2020)

\begin{abstract}
Summary: The purpose of this study was to clarify differences in energy values between a method proposed by the FAO using amino acid components, fatty acid components, carbohydrate components, etc. and the conventional (present) method. Methods: The energy values per $100 \mathrm{~g}$ of edible portions were calculated for the listed foods in the Standard Tables of Food Composition in Japan (new values), and compared with the listed energy values (present values). Next, using the intake amounts of each food in the National Health and Nutrition Examination Survey and the two types of energy values the two energy intakes were calculated, and these results were compared and examined. Results: The agreement rate between the new value per $100 \mathrm{~g}$ of edible portion and the current value was largest for algae (126\%) and smallest for vegetables $(76 \%)$. The concordance rate was less than $100 \%$ in 14 food groups, and the average concordance rate for the foods overall was $91 \%$. As for the concordance rate of individual foods, the $80-100 \%$ range included $68 \%$ of the target foods, $60-$ $80 \%$ included $13 \%$, and $100-120 \%$ included $12 \%$. From the rate of concordance between the total energy intake based on the new value calculated from the intake amounts determined in the National Health and Nutrition Examination Survey, the total daily energy intake per capita was $92 \%$ of the current values.
\end{abstract}

Key words: energy, energy by composition (component-based), protein by amino acid composition, fatty acids by triacylglycerol equivalent, available carbohydrates

* Corresponding author (E-mail: tomoko.watanabe@soc.shukutoku.ac.jp)

${ }^{1}$ Office for Resources, Ministry of Education, Culture, Sports, Science and Technology, 3-2-2 Kasumigaseki, Chiyoda-ku, Tokyo 100-8959, Japan

${ }^{2}$ Expert Committee on Food Components, 3-2-2 Kasumigaseki, Chiyoda-ku, Tokyo 100-8959, Japan

${ }^{3}$ Shukutoku University, 673 Nitona-cho, Chuo-ku, Chiba, Chiba 260-0801, Japan

${ }^{4}$ Food Research Institute, National Agriculture and Food Research Organization, NARO, 2-1-12 Kannon-dai, Tsukuba, Ibaraki 305-8642, Japan 